\title{
Study on firing temperature of the Song Dynasty (960-1279AD) greenish-white porcelain in Guangxi, China by thermal expansion method
}

\author{
Yongdong Tong ${ }^{1,2}$ and Changming Wang ${ }^{2^{*}}$
}

\begin{abstract}
The original firing temperatures of porcelain pieces unearthed from Tengxian Zhonghe kiln, Rongxian Chengguan kiln, Beiliu Lingdong kiln and Guiping Xishan kiln from the Song Dynasty (960-1279AD) of Guangxi were preliminarily studied by thermal expansion method. The experiment results show that the average firing temperature of Zhonghe kiln is $1186^{\circ} \mathrm{C}$ (standard deviation $59^{\circ} \mathrm{C}$ ), the firing temperature relatively concentrated and low. The average firing temperature of Chengguan kiln is $1233^{\circ} \mathrm{C}$ (standard deviation $46^{\circ} \mathrm{C}$ ), with the majority above $1200^{\circ} \mathrm{C}$, indicating that the kiln had a high and concentrated firing temperature. The average firing temperature of Lingdong kiln is $1250^{\circ} \mathrm{C}$ (standard deviation $87^{\circ} \mathrm{C}$ ), the firing temperature are in a broad spectrum. The firing temperatures of Xishan kiln are mostly over $1300^{\circ} \mathrm{C}$ (average $1307^{\circ} \mathrm{C}$, standard deviation $75^{\circ} \mathrm{C}$ ), which are generally considered very high, and the highest one it can go up to $1456^{\circ} \mathrm{C}$, which is the highest firing temperature of ancient Chinese ceramics known to date. Compared with the firing temperature of porcelain in other regions of China in Song Dynasty, it can be concluded that the high-temperature technology of Guangxi porcelain kilns was equal to or even advanced than other kilns. In the light of these findings, we conclude that the ancient Guangxi region of China did not lag behind the central plains in terms of ceramic firing technology and culture.
\end{abstract}

Keywords: Thermal expansion method, Song Dynasty, Greenish-white porcelain, Firing temperature

\section{Introduction and research aim}

The porcelain industry in Guangxi boomed during the Song Dynasty (960-1279AD), and dominated by two kiln systems of celadon and greenish-white porcelain. The celadon kiln sites are concentrated in northern Guangxi, mainly producing porcelain with cyan glaze and green glaze. The greenish-white porcelain kiln sites are concentrated in the southeast of Guangxi, consisting of three distribution areas: Beiliu river basin, Guiping and the upper reaches of Wusi river. There are more sites in Beiliu river basin than the other two areas. The main kilns (a whole production center comprising several

\footnotetext{
*Correspondence: b20180621@xs.ustb.edu.cn

${ }^{2}$ Archaeometry Laboratory, Guangxi University for Nationalities,

Nanning 530006, Guangxi, China

Full list of author information is available at the end of the article
}

kilns for porcelain production not a single kiln) include Tengxian Zhonghe kiln, Rongxian Chengguan kiln and Beiliu Lingdong kiln in the Beiliu river basin, the Guiping Xishan kiln and Weiyang kiln in Guiping area and the Tudong kiln in upper reaches of the Wusi river. The geographical locations of the four kilns (Tengxian Zhonghe kiln, Rongxian Chengguan kiln, Guiping Xishan kiln and Beiliu Lingdong kiln) studied in this paper are shown in Fig. 1. According to archaeological materials and studies, Zhonghe kiln existed between the middle Northern Song Dynasty (960-1127AD) and the late Southern Song Dynasty (1127-1279AD) [1]; Chengguan kiln emerged at about the same time or a bit earlier than Tengxian Zhonghe kiln, which began in the middle Northern Song Dynasty, and ended in the middle Southern Song Dynasty, the late Northern Song Dynasty through the early Southern Song Dynasty are its heyday 


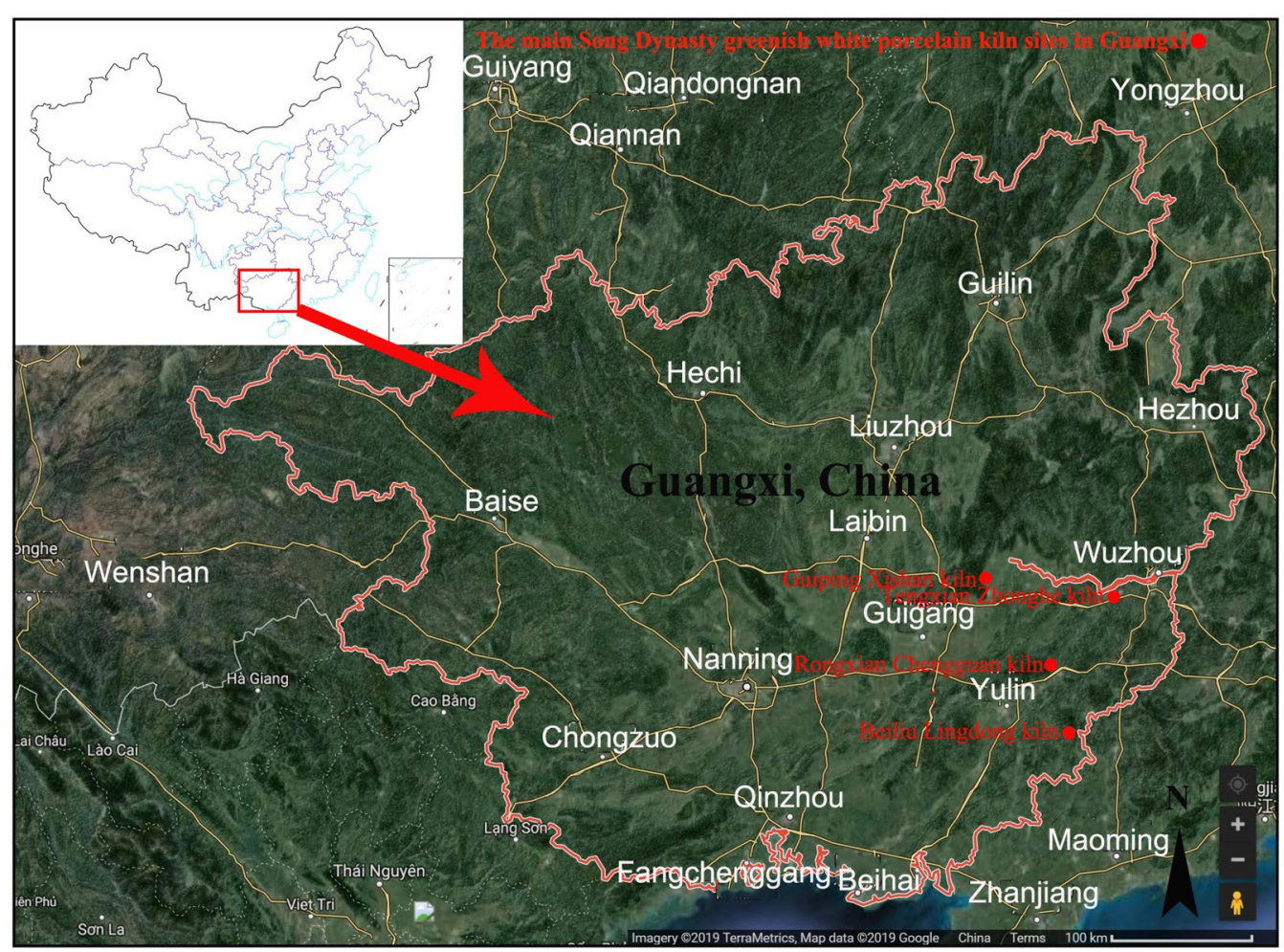

Fig. 1 Geographical distribution map of main greenish-white porcelain kiln sites of Song Dynasty in Guangxi, China

[1]; Lingdong kiln flourished in the early Southern Song Dynasty [2]; Guiping kiln appeared in the early Northern Song Dynasty, close to Five Dynasties (907-960AD), and ended in the early Huizong period (1100-1126AD) [3]. These kilns used to produce porcelain with a large quantity, high quality and superb techniques. Porcelain products were in various types and forms and made in a neat and delicate way, with a white and solid porcelain body, bright and translucent glaze, rich and colorful decoration techniques and patterns, and local characteristics. Figures 2 and 3 show the products of Zhonghe kiln and Chengguan kiln respectively.

The greenish-white porcelain of the Song Dynasty in Guangxi can be comparable to that of Jingdezhen for same period in terms of quality, and with a better techniques in certain areas. In particular, the high-temperature copper green glaze of the Rongxian Chengguan kiln is an innovation in the firing technology of Chinese ceramics during the Song Dynasty [1], which was of great significance in the history of Chinese ceramics. However, there is no record of the Guangxi greenish-white porcelain in the ancient Chinese literature, and few complete products currently exist. Therefore, little has been known of these porcelains.

Prior scientific researches on the ancient Chinese greenish-white porcelain have been mainly focused

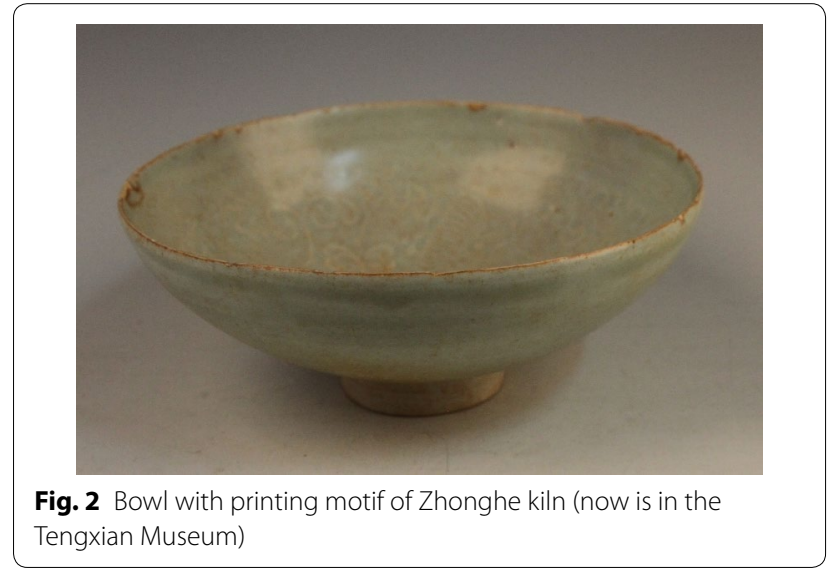

on the analysis of chemical components. For example, Cheng et al. [4, 5], Zhu et al. [6, 7] and Ming et al. [8] studied the chemical composition of the greenish-white porcelain in different areas of China by using various advanced techniques. However, there are very few studies concerning the determination of original firing temperatures of Chinese ceramics. The firing temperature is an important parameter to reflect the level of porcelain production, which is of great significance to the study of high-temperature technology of ancient ceramics and 


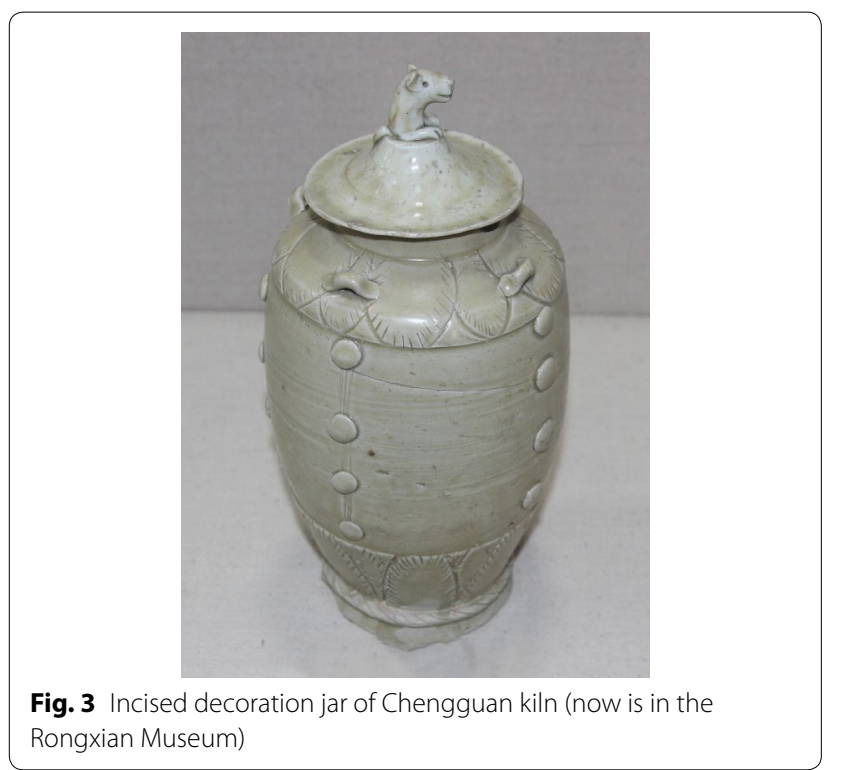

kilns. In the aspect of studying and determining the firing temperature of ancient ceramics, various methods and equipments were utilized including the magnetic susceptibility method [9, 10], Mössbauer spectra [11, 12], thermogravimetric differential thermal analysis [13], scanning electron microscope [14], electron paramagnetic resonance measurement [15-17] and the thermal expansion method. The thermal expansion method has been considered the most precise and direct to measure the firing temperature of ancient ceramics to date [18]. In 1959, Terrisse first introduced this method to the field of archaeology on the firing temperatures study [19]. In 1963, Roberts explained in detail the structure of the thermal dilatometer, the specific operation and analysis methods of temperature measurement [20]. In the 1960s, Tite proposed the theoretical hypothesis of this method [21] and then used it to determine the firing temperature of ancient ceramics from different periods, which had been found in Turkey, Iraq, Nigeria, England, China, and other countries [22]. In 2012, Pee et al. found that the variation in particle size for raw materials could lead to different shrinkage rates and changing starting temperature of shrinkage in the reheating process even with the same original firing temperature [23]. In 2018, Tong and Wang systematically studied the method by taking into account multiple factors including temperature rising rate, material type, sintering degree, and determination curve selection $[24,25]$.

The purpose of this paper is to study the firing temperature of the greenish-white porcelain unearthed from Song Dynasty kilns in Guangxi, China by using the thermal expansion method and to provide scientific data for the firing technology and porcelain research. Samples of porcelain pieces from four major greenish-white porcelain kilns, including Tengxian Zhonghe kiln, Rongxian Chengguan kiln, Beiliu Lingdong kiln, and Guiping Xishan kiln, were selected and utilized as research objects in this study.

\section{Experimental equipment and samples} Instrumentation

The DIL 402PC thermal dilatometer made by the German company NETZSCH was used in this study. Furnace body: $\mathrm{SiC}\left(0-1600{ }^{\circ} \mathrm{C} / 50 \mathrm{~K} / \mathrm{min}\right)$; Sample holder: tubular $\mathrm{Al}_{2} \mathrm{O}_{3}$ holder. The thermal analysis software is the Netzsch Proteus Thermal Analysis at version 6.1.0/12.08/2015.

\section{Sampling information}

Ten samples from the Zhonghe kiln were selected, which were collected at four different sites: Lishankou, Pingtouling, Feimaling, Feimaling primary school and Zhimaping. Six samples from the Chengguan kiln were selected, which were collected from the substation and rosin factory. Six samples from the Lingdong kiln were selected, which were collected from Lingdong kiln Y1. Ten samples from the Xishan kiln were selected, which were collected from Xungao kiln site and Guanchong kiln site near the park and Guishan village kiln site near the Guiping distillery. Some sample pictures are shown in Fig. 4. The sample number is a combination of kiln name, collection site and serial number, such as TZH-LSK-1, in which TZH is the abbreviation of Tengxian Zhonghe kiln, and LSK is the abbreviation of Lishankou, the collection site. LDY is the abbreviation of Lingdong kiln Y1.

\section{Sample preparation}

The sample preparation sequence is as follows: cleaning $\rightarrow$ drying $\rightarrow$ photographing and recording $\rightarrow$ cutting $\rightarrow$ grinding the end and bottom surfaces. The sample was further cut into rod-shaped rectangular pieces with a length of $25 \mathrm{~mm}$ and a width of 3-5 mm. In order to ensure that the pushrod, gasket, and samples expand or contract in the same straight line during the heating process, the two end faces of the sample should be absolutely parallel to each other, and the bottom face and two end faces should be flat and smooth.

\section{Method and experiment Method}

Thermal expansion method is based on the following theoretical hypotheses: When a ceramic material with a certain firing temperature is heated from room temperature to its original firing temperature, the material exhibits normal reversible thermal expansion; If the temperature 


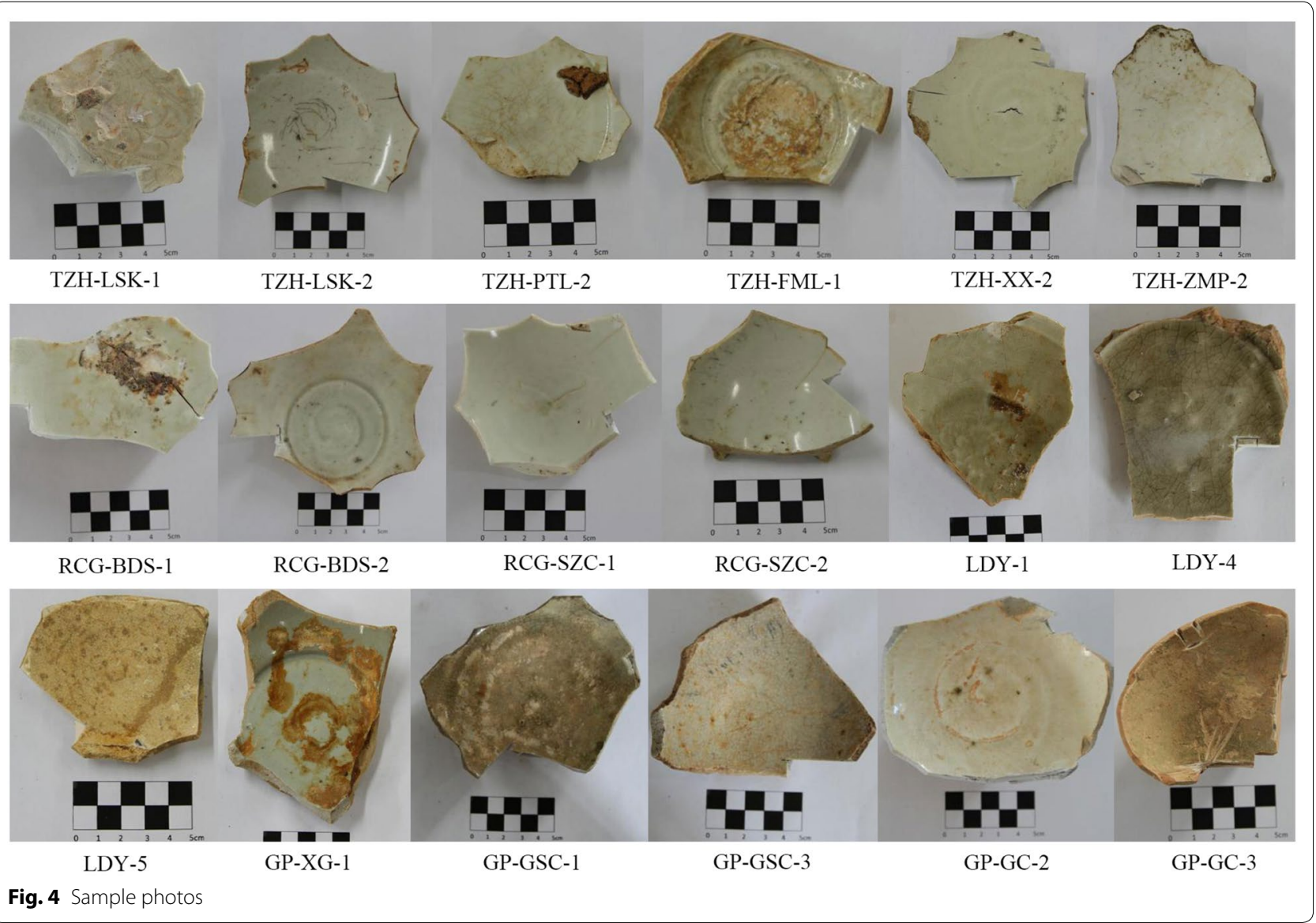

continues to rise, due to the continuation and deepening of sintering, irreversible rapid shrinkage will be superimposed on the existing reversible expansion. The starting point of the superposition contraction is usually called the net shrinkage temperature. The net shrinkage temperature corresponding to the first net shrinkage on the thermal expansion curve is infinitely close to the original firing temperature, that is the judgment basis for determining the firing temperature with the thermal expansion method. Figure 5 shows the thermal expansion curve of high-alumina ceramic materials, which had an original firing temperature of $1250{ }^{\circ} \mathrm{C}$, and was heated from room temperature to $1400{ }^{\circ} \mathrm{C}$. It can be seen from the figure that the temperatures corresponding to the net shrinkage of $\mathrm{dL}$ curve ( thermal expansion curve) and $\mathrm{dL} / \mathrm{dt}$ curve (first derivative of thermal expansion curve) can be used to determine the original firing temperatures.

The accuracy and directness of thermal expansion method are reflected in that the determination basis (net shrinkage) of firing temperature corresponds directly to the temperature, unlike other methods which derive the firing temperature indirectly according to the chemical or physical changes of the material. The thermal expansion

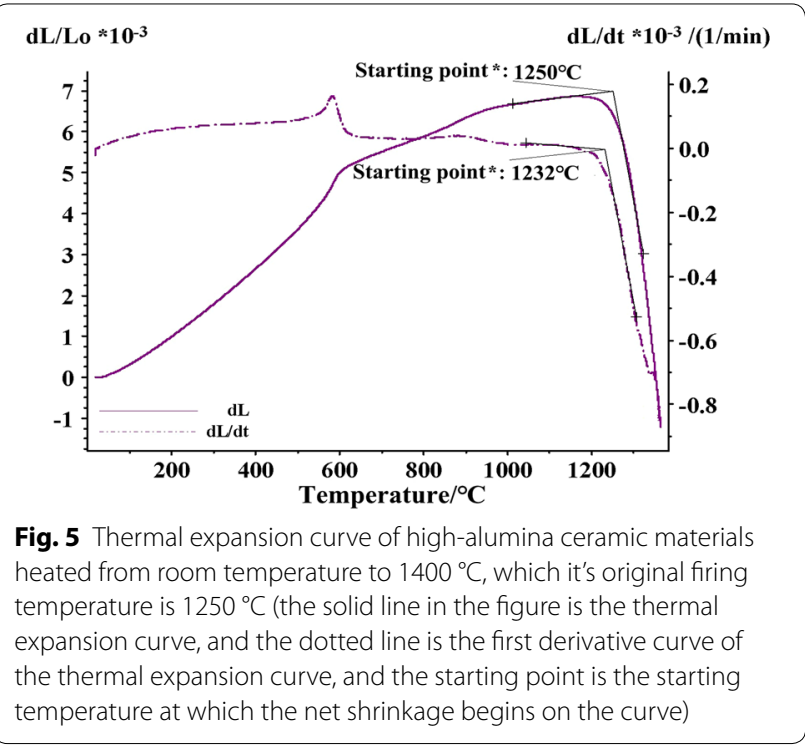

method has also good repeatability, that is, for the same samples in the same test conditions the measurement results are almost identical during multiple testing. 
However, there is uncertainty for this method. For example, the temperature rising rate, types of ceramic material, degree of sintering, determination curve selection and different analysis methods will bring uncertainty to the measurement results. In addition, some ceramic materials internally will undergo phase transition or generate gas at a specific temperature, and the expansion or contraction accompanied by phase transition or generated gas will cover or affect the net shrinkage, thus bringing uncertainty to the determination of the final result. Fortunately, to determine the final firing temperature we have done a large number of simulated experiments under various conditions, and now we have a new understanding of the rule of uncertainty of temperature measurement results, and can receive the results (the uncertainty is within $17^{\circ} \mathrm{C}$ ) close to the actual firing temperature by a calibrating procedure and formula [24].

\section{Experiment}

The "correction + sample" mode was selected for sample testing, and the softening point detection was set to prevent the sample from melting and contaminate the sample holder at a high temperature. The "correction + sample" mode can deduct the expansion of the instrument system itself automatically during the testing and can reflect the expansion or contraction of the sample at high temperature more accurately. Prior temperature measurement simulation experiments show that more accurate temperature measurement results can be obtained for ceramic materials with higher aluminum content at higher temperature rate. The optimal heating rate of the high alumina-ceramic material $\left(\mathrm{Al}_{2} \mathrm{O}_{3}\right.$ content $\geq 26.4 \%$ ) used in the simulation experiment is $7.5 \mathrm{~K} /$ min [24]. Among the 32 porcelain samples in this test, RCG-BDS-1 and RCG-SZC-1 samples have an extremely delicate and white porcelain body, and the content of aluminum in porcelain bodies is equal to or even higher than that of the high-alumina materials in the simulation experiment [26]. Therefore, the temperature rising rate of the above two porcelain samples are set at $7.5 \mathrm{~K} / \mathrm{min}$; The aluminum content of the remaining samples are slightly lower or lower than that of the high-alumina ceramic materials used in the simulation experiment, so the heating rate are set as $5 \mathrm{~K} / \mathrm{min}$.

\section{Results and discussion}

The experimental study on the simulated temperature measurement of high-alumina ceramic materials $\left(\mathrm{Al}_{2} \mathrm{O}_{3}\right.$ content $\geq 26.4 \%$ ) with high kaolin content shows that the starting point of net shrinkage on the dL curve is the most appropriate final temperature measurement result [24]. The Zhonghe kiln porcelain body is white and delicate, and the content of $\mathrm{Al}_{2} \mathrm{O}_{3}$ in porcelain body is about
$25 \%$ [26], which is similar to the content of $\mathrm{Al}_{2} \mathrm{O}_{3}$ in the ceramic material selected in the simulation experiment. Therefore, in the final temperature measurement results of these 10 samples, the $\mathrm{dL}$ curve was used as their determination curve, which means that the starting point of net shrinkage on the $\mathrm{dL}$ curve was the measured value. The content of $\mathrm{Al}_{2} \mathrm{O}_{3}$ in Chengguan kiln porcelain body is similar to that in Zhonghe kiln porcelain [26], so the $\mathrm{dL}$ curve was also selected for the determination curve. In the 6 samples of Lingdong kiln, except LDY-5, other porcelain samples are similar in porcelain body to Zhonghe kiln and Chengguan kiln porcelain, but slightly darker in color. Therefore, the $\mathrm{dL}$ curve is again selected as the determination curve for temperature measurement results of all samples except LDY-5. The LDY-5 porcelain sample belongs to low-aluminum clay material type, and low-aluminum clay materials in the simulated temperature measuring experiment show that with a heating rate of $5 \mathrm{~K} / \mathrm{min}$, if the measured value of the $\mathrm{dL} / \mathrm{dt}$ curve falls between 1080 and $1200{ }^{\circ} \mathrm{C}$, the measurement is accurate based on the measured value of the $\mathrm{dL} / \mathrm{dt}$ curve [25]. The temperature measurements of many porcelain samples from the Xishan kiln were higher than $1250{ }^{\circ} \mathrm{C}$ determined by the $\mathrm{dL} / \mathrm{dt}$ curve. According to the simulation experimental study, the measured values determined by the $\mathrm{dL} / \mathrm{dt}$ curve under the heating rate of $5 \mathrm{~K} / \mathrm{min}$ were clearly higher than $1250{ }^{\circ} \mathrm{C}$ or lower than $1080^{\circ} \mathrm{C}$, so the correction formula $\mathrm{T}=1.13732 \mathrm{Tm}-161$ ( $\mathrm{T}$ is the final determined value and $\mathrm{Tm}$ is the measured value) should be used [24]. Therefore, when the final temperature measurement results are determined, some should be corrected as required.

Figures 6 and 7 show the two special thermal expansion curves in this temperature measurement study. The measured values determined by the $\mathrm{dL}$ curve and the dL/dt curve in Fig. 6 are quite different from each

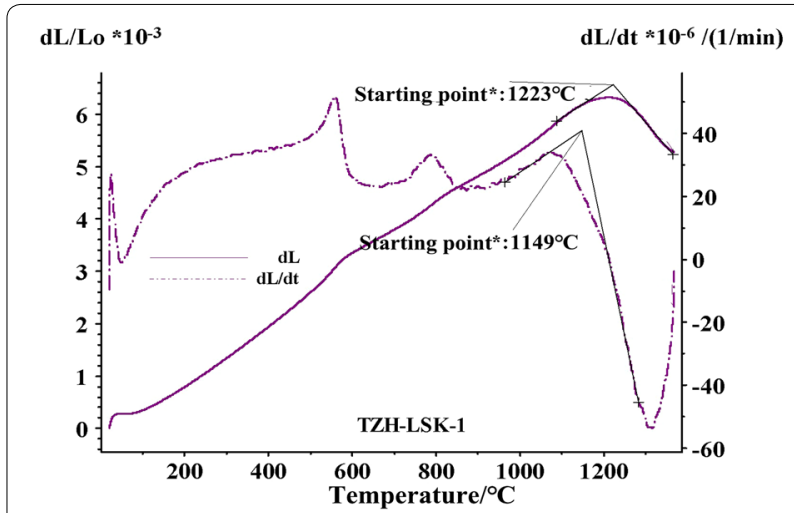

Fig. 6 Thermal expansion curve of TZH-LSK-1 sample (description as in Fig. 5) 


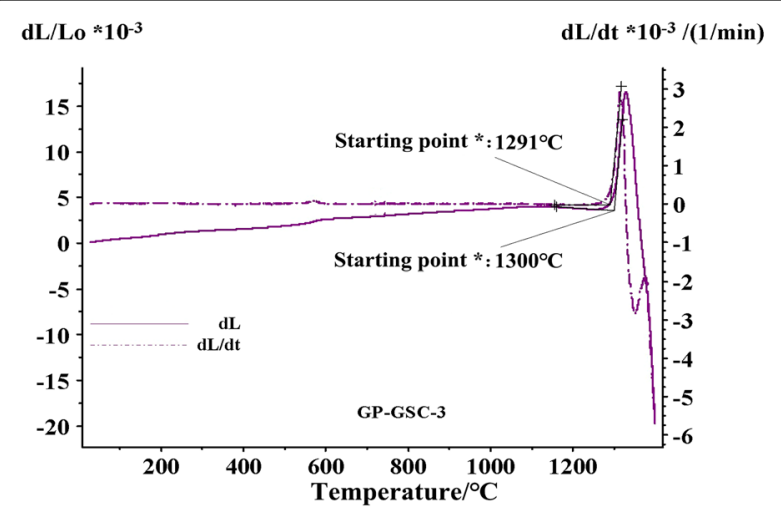

Fig. 7 Thermal expansion curve of GP-GSC-3 sample (the solid line in the figure is the thermal expansion curve, and the dotted line is the first derivative curve of the thermal expansion curve, and the starting point is the starting temperature at which the abrupt expansion begins on the curve)

other. The simulation experiment shows that the net shrinkage temperature on the $\mathrm{dL}$ curve is very close to the actual firing temperature. In Fig. 7, an abrupt expansion occurs on the $\mathrm{dL}$ curve and then rapid contraction occurs. According to our research [24], the abrupt expansion is caused by the gas generated inside the porcelain body after the refiring temperature exceeds the original firing temperature. In this case, the temperature corresponding to the abrupt expansion starting point is the closest to the actual firing temperature, but not the temperature corresponding to the net shrinkage starting point. Specific reasons and analysis methods references to literature [24].

Temperature measurement results are shown in Table 1. The results indicate that the ten Zhonghe kiln samples have firing temperature between 1087 and $1289^{\circ} \mathrm{C}$, with an average of $1186^{\circ} \mathrm{C}$ and a standard deviation of $59^{\circ} \mathrm{C}$, and these firing temperature is relatively concentrated and low. The firing temperatures of the six porcelain samples from the Chengguan kiln are between 1189 and $1320^{\circ} \mathrm{C}$, with an average of $1233^{\circ} \mathrm{C}$ and a standard deviation of $46^{\circ} \mathrm{C}$, with most of them above $1200{ }^{\circ} \mathrm{C}$. The firing temperature are high and concentrated. Chengguan kiln and Zhonghe kiln are close to each other both geographically and in historical time, the color and texture of their product bodies are almost identical and the chemical composition of porcelain body is very similar [26], which indicates that the two kilns are essentially the same in raw material selection. But in terms of firing temperature, the average firing temperature of Chengguan kiln porcelain is nearly $50^{\circ} \mathrm{C}$ higher than that of the Zhonghe kiln porcelain, which shows that the high-temperature firing technology of Chengguan kiln is superior to that of Zhonghe kiln.
The firing temperatures of 6 porcelain samples from Lingdong kiln range from 1112 to $1337^{\circ} \mathrm{C}$, with an average of $1250{ }^{\circ} \mathrm{C}$ and a standard deviation of $87^{\circ} \mathrm{C}$, the firing temperatures are in a broad spectrum. This could explain why the high-temperature firing technology level of Lingdong kiln Y1 was not consistent, but rather it was changing. Lingdong kiln Y1 is different from other ancient kiln sites in Guangxi. Its scale is extremely huge, and the 108-m-long kiln bodies are still visible winding and creeping all over the hillside [27]. Even in the same batch in this long kiln, the firing temperatures of porcelain varied greatly depending upon the positions they were placed in the kiln. In our study, the firing temperatures of two porcelain samples exceeded $1300{ }^{\circ} \mathrm{C}$, and Lingdong kiln possess a high level of firing technology, better than that of Zhonghe kiln in the same period, and slightly better or equivalent to that of Chengguan kiln.

All of ten porcelain samples from Xishan kiln, excepting GP-GC-3 which had the lowest firing temperature $\left(1164{ }^{\circ} \mathrm{C}\right)$, all the rest were over $1250{ }^{\circ} \mathrm{C}$, with the overwhelming majority exceeding $1300{ }^{\circ} \mathrm{C}$, and the highest standing at $1456{ }^{\circ} \mathrm{C}$. The porcelain body color of the GP-GC-3 sample is red clay color, and a layer of white soil exists between the body and the glaze. These characteristics are very different from the other 9 samples of Xishan kiln, indicating that this sample is completely different from other porcelain in raw material selection and creation technology. Considering the characteristics of high ring foot of this porcelain, this sample is probably a product of an early stage of the Northern Song Dynasty. Therefore, this sample is an exception, and not representing the high temperature firing technical level of Xishan kiln. Though the color and texture of the other 9 samples are not as white and delicate as the porcelain of Zhonghe kiln, Chengguan kiln and Lingdong kiln, in terms of firing temperature Xishan kiln averages $121^{\circ} \mathrm{C}$ higher than Zhonghe kiln, $74{ }^{\circ} \mathrm{C}$ higher than Chengguan kiln, and $57^{\circ} \mathrm{C}$ higher than Lingdong kiln.

The $\mathrm{P}$ values given by $\mathrm{t}$ test for the differences in firing temperatures of different kilns are shown in Table 2. According to the $\mathrm{P}$ values, at significance level $\mathrm{a}=0.1$, the firing temperature of Zhonghe kiln have a statistically difference from that of Chengguan kiln $(P=0.06)$, significantly difference from that of Lingdong kiln $(P=0.05)$, and extremely significantly difference from that of Xishan kiln $(P=0)$, which reflects that the hightemperature firing technology of Zhonghe kiln has a certain gap with that of Chengguan kiln, a significant gap with that of Lingdong kiln, and a very large gap with that of Xishan kiln; The firing temperature of Chengguan kiln have no statistically difference from that of Lingdong kiln $(P=0.34)$, while have a significantly difference from that of Xishan kiln $(\mathrm{P}=0.02)$, 
Table 1 Temperature measurement results

\begin{tabular}{|c|c|c|c|c|c|c|}
\hline Kiln & Samples number & $\begin{array}{l}\text { The value } \\
\text { determined } \\
\text { by the } \mathrm{dL} \text { curve } /{ }^{\circ} \mathrm{C}\end{array}$ & $\begin{array}{l}\text { The value determined } \\
\text { by the } \mathrm{dL} / \mathrm{dt} \text { curve } /{ }^{\circ} \mathrm{C}\end{array}$ & $\begin{array}{l}\text { Final temperature } \\
\text { measurement } \\
\text { results } /{ }^{\circ} \mathrm{C}\end{array}$ & $\begin{array}{l}\text { Average firing } \\
\text { temperature } /{ }^{\circ} \mathrm{C}\end{array}$ & $\begin{array}{l}\text { The } \\
\text { standard } \\
\text { deviation/o }\end{array}$ \\
\hline \multirow[t]{10}{*}{ Zhonghe kiln } & TZH-LSK-1 & 1223 & 1149 & 1223 & \multirow[t]{10}{*}{1186} & \multirow[t]{10}{*}{59} \\
\hline & TZH-LSK-2 & 1156 & 1127 & 1156 & & \\
\hline & TZH-PTL-1 & 1227 & 1215 & 1227 & & \\
\hline & TZH-PTL-2 & 1172 & 1101 & 1172 & & \\
\hline & TZH-FML-1 & 1117 & 1101 & 1117 & & \\
\hline & TZH-FML-2 & 1087 & 1027 & 1087 & & \\
\hline & TZH-XX-1 & 1201 & 1154 & 1201 & & \\
\hline & TZH-XX-2 & 1289 & 1280 & 1289 & & \\
\hline & TZH-ZMP-1 & 1217 & 1119 & 1217 & & \\
\hline & TZH-ZMP-2 & 1166 & 1126 & 1166 & & \\
\hline \multirow[t]{6}{*}{ Chengguan kiln } & RCG-BDS-1 & 1320 & 1343 & 1320 & \multirow[t]{6}{*}{1233} & \multirow[t]{6}{*}{46} \\
\hline & RCG-BDS-2 & 1208 & 1201 & 1208 & & \\
\hline & RCG-BDS-3 & 1189 & 1177 & 1189 & & \\
\hline & RCG-SZC-1 & 1208 & 1175 & 1208 & & \\
\hline & RCG-SZC-2 & 1239 & 1130 & 1239 & & \\
\hline & RCG-SZC-3 & 1235 & 1240 & 1235 & & \\
\hline \multirow[t]{6}{*}{ Lingdong kiln } & LDY-1 & 1321 & 1309 & 1321 & \multirow[t]{6}{*}{1250} & \multirow[t]{6}{*}{87} \\
\hline & LDY-2 & 1181 & 1163 & 1181 & & \\
\hline & LDY-3 & 1272 & 1262 & 1272 & & \\
\hline & LDY-4 & 1337 & 1310 & 1337 & & \\
\hline & LDY-5 & 1141 & 1112 & 1112 & & \\
\hline & LDY-6 & 1278 & 1202 & 1278 & & \\
\hline \multirow{10}{*}{$\begin{array}{l}\text { Guiping } \\
\text { Xishan kiln }\end{array}$} & GP-XG-1 & 1358 & 1334 & 1358 & \multirow[t]{10}{*}{1307} & \multirow[t]{10}{*}{75} \\
\hline & GP-XG-2 & 1312 & - & 1312 & & \\
\hline & GP-XG-3 & 1301 & 1291 & 1307 (after correction) & & \\
\hline & GP-GSC-1 & 1456 & 1432 & 1456 & & \\
\hline & GP-GSC-2 & 1303 & 1217 & 1303 & & \\
\hline & GP-GSC-3 & 1300 & 1291 & 1307 (after correction) & & \\
\hline & GP-GC-1 & 1325 & 1321 & 1342 (after correction) & & \\
\hline & GP-GC-2 & 1274 & 1254 & 1274 & & \\
\hline & GP-GC-3 & 1184 & 1164 & 1164 & & \\
\hline & GP-GC-4 & 1250 & 1222 & 1250 & & \\
\hline
\end{tabular}

Table 2 P values given by $t$ test for difference of firing temperature between different kilns

\begin{tabular}{llll}
\hline Kilns & & $\begin{array}{l}\text { P values (one- } \\
\text { tail test) }\end{array}$ & $\begin{array}{l}\text { P values } \\
\text { (two-tailed } \\
\text { test) }\end{array}$ \\
\hline Zhonghe kiln & Chengguan kiln & 0.06 & 0.11 \\
Zhonghe kiln & Lingdong kiln & 0.05 & 0.10 \\
Zhonghe kiln & Xishan kiln & 0 & 0 \\
Chengguan kiln & Lingdong kiln & 0.34 & 0.68 \\
Chengguan kiln & Xishan kiln & 0.02 & 0.05 \\
Lingdong kiln & Xishan kiln & 0.09 & 0.19 \\
\hline
\end{tabular}

which reflects that the high-temperature firing technology of Chengguan kiln is roughly equivalent to that of Lingdong kiln, and there is a significant gap with that of Xishan kiln; There are a statistical difference between the firing temperature of Lingdong kiln and that of Xishan kiln $(P=0.09)$, which reflects a certain gap in the high-temperature firing technology between the two kilns.

The box plot of the firing temperature of the four main greenish-white porcelain kilns mentioned above is shown in Fig. 8. It can be intuitively seen from the figure that the box shape of Chengguan kiln is very narrow, which reflects the concentrated distribution of temperature measurement data; The box shape of 


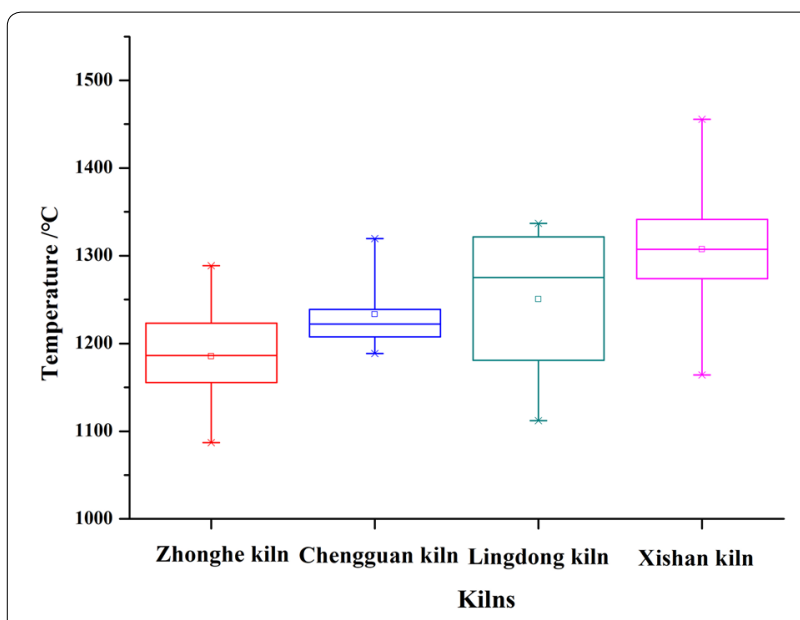

Fig. 8 Box plot of firing temperature of four main greenish white porcelain kilns

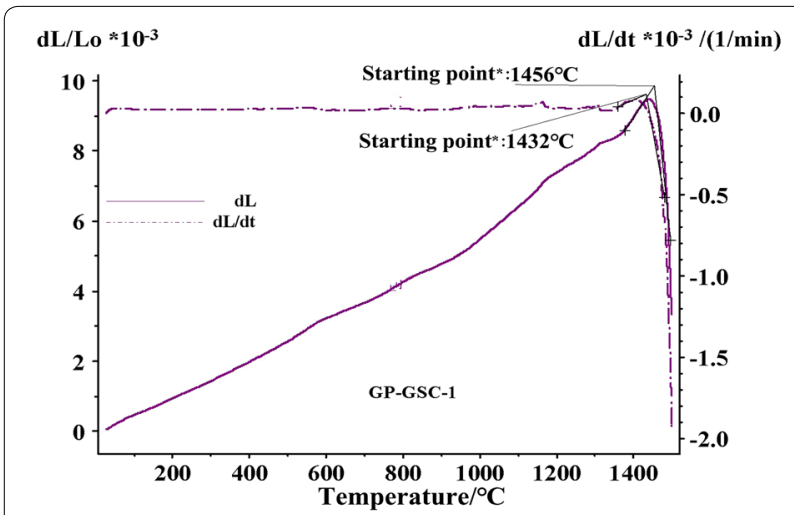

Fig. 9 Thermal expansion curve of GP-GSC-1 sample (the description is the same as in Fig. 5)

Lingdong kiln is very wide, which reflects the wide distribution of temperature measurement data; while the median value is biased to the upper quartile, indicating that the temperature measurement data tend to the direction of high-temperature value; The box shape of Zhonghe kiln is relatively narrow, with relatively concentrating temperature data distribution; The distance between upper limit and lower limit of temperature measurement data of Xishan kiln is very wide, but the box shape is relatively narrow, and the temperature measurement data are concentrated between upper quartile and lower quartile. The smallest box within each box represents the average firing temperature of the corresponding kiln.

In this study, it is worth noting that the firing temperature of GP-GSC-1 of Xishan kiln porcelain samples reached $1456{ }^{\circ} \mathrm{C}$, which is the highest record of all ancient Chinese ceramics known to date [28]. The temperature measurement curve is shown in Fig. 9. The porcelain body of this sample is gray, with fine texture and solidity, and the re-firing test shows that the porcelain sample neither deformed or melted even at the high temperature of $1500{ }^{\circ} \mathrm{C}$. Therefore, the porcelain sample has not been over-fired. Considering that the firing temperatures of other porcelain samples in Xishan kiln were generally very high, it indicates that the high temperature firing technology level of Xishan kiln is exceptional. The high firing temperature of Xishan kiln could be primarily related to ceramic raw materials, kiln structure, fuel and firing craftmanship of kiln workers. According to Zhou's study, the content of $\mathrm{Al}_{2} \mathrm{O}_{3}$ in porcelain body of Zhonghe kiln, Chengguan kiln, and Xishan kiln is higher, around $25 \%$ [26]. This raw material belongs to the type of high-alumina material, which has a high fire resistance and cannot be fully densified until at least $1300{ }^{\circ} \mathrm{C}$ [29]. Because the color and texture of porcelain in Xishan kiln is not as white and delicate as those in Zhonghe, Chengguan, and Lingdong kilns, due to lower quality of ceramic raw materials than those kilns, the important method to improve the quality of porcelain is to increase the firing temperature as much as possible. In terms of kiln structure, Xishan kiln is a short, thick and straight tube with no kiln door on the sidewall [3], which is obviously different from Zhonghe kiln, Chengguan kiln, Lingdong kiln, and other long dragon kilns. This short and thick straight cylindrical kiln has a much smaller capacity of porcelain than a dragon kiln, but with a high heat efficiency, which makes it easier to reach a high temperature. Another reason for the Xishan kiln's high fire temperature is the existing of abundance of fuel. Guiping belonged to the ancient Rongzhou, where large pine trees grow during the Song Dynasty, and plenty of good fuel was available around Xishan kiln at that time. In the Song Dynasty, the greenish-white porcelain industry in the southeast of Guangxi formed a large industrial conglomerate, and there must have been no shortage of skilled kiln workers. So in summary, the intrinsic demand of porcelain quality, unique kiln structure, the abundance of excellent fuel and experienced kiln workers have created the hightemperature porcelain of Xishan kiln. Above all, in the main greenish-white porcelain kilns in ancient Guangxi, although the material selection of the porcelain from Xishan kiln is less superior as that of other kilns, it is absolutely outstanding in terms of the high-temperature level of the kiln. In particular, the finding of ancient porcelain with the highest firing temperature from Xishan kiln, which reflects its superb high-temperature firing technology level.

The increasing firing temperature is one of the three technological breakthroughs in the history of ancient Chinese ceramics. From an average firing temperature 
of pottery at $920{ }^{\circ} \mathrm{C}$ to that of printed hard pottery at $1080{ }^{\circ} \mathrm{C}$ in the Shang and Zhou Dynasties (circa 1600$256 \mathrm{BC}$ ), the gradual temperature increase heralds the first breakthrough of high-temperature technology in the history of Chinese ceramics [30]. In the Tang Dynasty (618-907AD), the average firing temperature of northern white porcelain was about $1240{ }^{\circ} \mathrm{C}$ [30], which was considered the second historical breakthrough in the high-temperature technology of Chinese ceramics. In the Song Dynasty (960-1279AD), the average firing temperature of the porcelain in the official kilns was as high as about $1270{ }^{\circ} \mathrm{C}$ [31], and that in some folk kilns, such as Xianghu kiln in Jingdezhen and Dehua kiln in Fujian, was also high, and could reach $1230{ }^{\circ} \mathrm{C}[32]$ and $1260{ }^{\circ} \mathrm{C}$ [30] respectively. The average firing temperature of porcelain from Hutian kiln in Jingdezhen and Jizhou kiln in Jiangxi are relatively low, below than $1200{ }^{\circ} \mathrm{C}[33,34]$. The research results of this paper show that the average firing temperature of the Song Dynasty Zhonghe kiln, Chengguan kiln, Lingdong kiln, and Xishan kiln in Guangxi were up to $1186^{\circ} \mathrm{C}, 1233{ }^{\circ} \mathrm{C}, 1250{ }^{\circ} \mathrm{C}$ and $1307^{\circ} \mathrm{C}$ respectively. The comparison between the average firing temperature of kiln in the Song Dynasty in Guangxi and that in other parts of China shows that the firing temperature of Zhonghe kiln is basically the same as that of Hutian kiln and Jizhou kiln, and the average firing temperature is below $1200{ }^{\circ} \mathrm{C}$; The average firing temperature of Chengguan kiln is similar to that of Xianghu kiln, about $1230^{\circ} \mathrm{C}$; The average firing temperature of Lingdong kiln is close to that of Dehua kiln, about $1250-1260^{\circ} \mathrm{C}$; The high-temperature technology of Xishan kiln is clearly advanced, since its average firing temperature reaches $1307^{\circ} \mathrm{C}$, and is more than $30^{\circ} \mathrm{C}$ higher than that of official kiln in the Song Dynasty. The above comparative analyses indicate that the high-temperature technical level of Guangxi porcelain kilns in the Song Dynasty is equal to or even better than that of other Song Dynasty porcelain kilns in China. Considering the fact that Guangxi was in a remote southern border area, and far from the culture and economic center in ancient China, its high-temperature technology was a remarkable achievement.

\section{Conclusions}

Though a large of number porcelain kiln sites have been discovered in Guangxi, few scientific research has been conducted. In general, the porcelain discovered in Guangxi in the Song Dynasty is not as much important as contemporary famous porcelain manufactured from north or other regions of China. However, the results of this study indicate that the firing technology of greenishwhite porcelain of Guangxi did not lag behind other areas in China in the Song Dynasty. Some kilns of Guangxi were even in a countrywide leading position in terms of firing technology in the Song Dynasty. This is a significant result. There still remain questions such as why so many porcelain kilns developed in the Song Dynasty in Guangxi, a borderland region of China and why those greenish-white porcelain kilns managed to develop those superb firing knowhow. Perhaps the greatest significance of this paper is that it raises more questions whose answers require further scientific research.

\section{Abbreviation \\ DIL: dilatometer. \\ Acknowledgements \\ Not applicable. \\ Authors' contributions \\ CMW created the study idea and oversaw the whole work. YDT conducted all the experiments including the data analysis and drafted the manuscript. Both authors helped revise the manuscript. Both authors read and approved the final manuscript. \\ Funding \\ The study is funded by the natural science foundation of Guangxi (2018GXNS- FAA294094); Reform and innovation program of degree and postgraduate education in Guangxi university for nationalities (gxun-chxjg201701).}

Availability of data and materials

Not applicable.

Ethics approval and consent to participate

Not applicable.

\section{Competing interests}

The authors declare that they have no competing interests.

\section{Author details}

${ }^{1}$ Institute of Culture Heritage and History of Science \& Technology, University of Science and Technology Beijing, Beijing 100083, China. ${ }^{2}$ Archaeometry Laboratory, Guangxi University for Nationalities, Nanning 530006, Guangxi, China.

Received: 12 April 2019 Accepted: 29 August 2019

Published online: 12 September 2019

References

1. Wei RY. Greenish white porcelain from Guangxi in Song Dynasty. Jingdezhen's Ceram. 1993;3:11-4 (in Chinese).

2. Jiang TY. General theory of Guangxi archaeology. Nanning: Guangxi Science and Technology Press; 2012 (in Chinese).

3. Zhang SQ. The Song porcelain kilns at Guiping. Guangxi Acta Archaeologica Sinica. 1983;37:501-19 (in Chinese).

4. Cheng L, Ding XL, Feng SL, Cheng HS, Zhang WJ, Fan CS. PIXE analysis of Chinese ancient greenish white porcelain. Nucl Instrum Methods Phys Res Sect B. 2006:244:409-11.

5. Cheng L, Li MT, Wang JL, Li RW. The study of ancient porcelain of Hutian kiln site from five dynasty (902-979) to Ming dynasty (1368-1644) by INAA. J Radioanal Nucl Chem. 2015;304:817-22.

6. Zhu TQ, Wang CS, Wang HM, Mao ZW. The preliminary study on kiln identification of Chinese ancient Qingbai wares by ICP-AES. J Cult Herit. 2010;11:482-6.

7. Zhu TQ, Sun WD, Zhang H, Wang HM, Kuang GR, Lv L. Study on the provenance of Xicun Qingbai wares from the northern Song Dynasty of China. Archaeometry. 2012;54:475-88.

8. Ming CF, Yang YM, Zhu J, Guan L, Fan CS, Xu CQ, Yao ZQ, Kenoyer JM, Song GD, Wang CS. Archaeometric investigation of the relationship 
between ancient egg-white glazed porcelain (Luanbai) and bluish white glazed porcelain (Qingbai) from Hutian Kiln, Jingdezhen. China J Archaeol Sci. 2014;47:78-84.

9. Rasmussen KL, De La Fuente GA, Bond AD, Mathiesen KK, Vera SD. Pottery firing temperatures: a new method for determining the firing temperature of ceramics and burnt clay. J Archaeol Sci. 2012;39:1705-16.

10. Kostadinova-Avramova M, Jordanova N, Jordanova D, Grigorov $V_{\text {, }}$ Lesigyarski D, Dimitrov P, Bozhinova E. Firing temperatures of ceramics from Bulgaria determined by rock-magnetic studies. J Archaeol Sci Rep. 2018;17:617-33.

11. Gao ZY, Chen SH, Chen XD. Mössbauer study of the Ru porcelain of Chinese Song Dynasty and Yuan Dynasty. Hyperfine Interact. 1994;91:663-8.

12. Tominaga T, Takeda M, Mabuchi $H$, Emoto Y. Characterization of ancient Japanese roofing tiles by 'Fe Mössbauer spectroscopy. Archaeometry. 2007:20:135-46.

13. Bayazit M, Işık I, Issi A. Investigating the firing technologies of Part-Roman potsherds excavated from Kuriki (Turkey) using thermal and vibrational spectroscopic techniques. Vib Spectrosc. 2015;78:1-11.

14. Bertolino SR, Fabra M. Provenance and ceramic technology of pot sherds from ancient Andean cultures at the Ambato valley. Argentina Appl Clay Sci. 2003;24:21-34.

15. Yves B, Bruno D, Sandrine C, Jean-Victor Z. Electron spin resonance and dilatometric studies of ancient ceramics applied to the determination of firing temperature. Jpn J Appl Phys. 1998;37:4367-72.

16. Felicissimo MP, Peixoto JL, Bittencourt C, Tomasi R, Houssiau L, Pireaux JJ, Rodrigues-Filho UP. SEM, EPR and ToF-SIMS analyses applied to unravel the technology employed for pottery-making by pre-colonial Indian tribes from Pantanal, Brazil. J Archaeol Sci. 2010;37:2179-87.

17. Cano NF, Ribeiro RB, Munita CS, Watanabe MS, Neves EG, Tamanaha EK. Dating and determination of firing temperature of ancient potteries from São Paulo II archaeological site, Brazil by TL and EPR techniques. J Cult Herit. 2015;16:361-4.

18. Zhu J, Zhang Y, Wang T, Zhao CH, Yu JC, Glascock MD, Wang CS. Determining the firing temperature of low-fired ancient pottery: an example from the Donghulin Site, Beijing. China Archaeom. 2013;56:562-72.

19. Terrisse JR. Study on the technique of the sigillated earthenware. Assoc Roman Ceram Archaeol. 1959;2:63.

20. Roberts JP. Determination of the firing temperature of ancient ceramics by measurement of thermal expansion. Archaeometry. 1963;6:21-5.

21. Tite MS. Determination of the firing temperature of ancient ceramics by measurement of thermal expansion: a reassessment. Archaeometry. 1969;11:131-43.

22. Tite MS. Determination of the firing temperature of ancient ceramics by measurement of thermal expansion. Nature. 1969;222:81.
23. Pee JH, Lee EM, Kim GH, Kim YJ, Kim KJ, Gang Gl, Jung DS, Katsuki H. Evaluation of firing temperature of the Bangsan Porcelain. Key Eng Mater. 2012;512-515:666-70.

24. Tong YD. Multi-factor analysis of firing temperature measurement by thermal expansion method and its application to Guangxi ancient ceramics [Master dissertation]. Nanning: Guangxi University for Nationalities; 2018 (in Chinese).

25. Wang CM, Tong YD. The simulation experiment research of the thermal expansion technology in determination of the firing temperature of ancient ceramics. Sci Technol Eng. 2018;18:86-91 (In Chinese)

26. Zhou BY. Scientific research on Bluish white Porcelain from Zhonghe kiln in Guangxi [Master dissertation]. Nanning: GuangXi University for Nationalities; 2016 (in Chinese)

27. Peng CL. The Song dynasty kiln site in Lingdong, Beiliu city, Almanac of Chinese archaeology. Beijing: Cultural Relics Press; 1996 (in Chinese).

28. Lu XK, Li WD, Luo HJ, Han LS, Wang HM, Li Q. Scientific research of Xing kiln. Scientia Sinica. 2012;42:1204-21 (in Chinese)

29. Gao AS. Some thoughts on the firing temperature of porcelain. Collectors. 2006;13:33-40 (in Chinese).

30. Li JZ. History of science and technology in China ceramic volumes. Beijing: Science Press; 1998 (in Chinese)

31. Wang HM. Comprehensive scientific analyses of porcelains of the Song Dynasty [PhD dissertation]. Hefei: University of Science and Technology of China; 2010 (in Chinese)

32. Ouyang RF. Comparative study on the evolution from white porcelain in five dynasties to greenish white porcelain in Song Dynasty in Jingdezhen [Master dissertation]. Jingdezhen: Jingdezhen ceramic Institute; 2014 (in Chinese)

33. Wu JM, Wu L, Ding YZ, Yuan F, Fang T. Chemical composition and technological characteristics of brown, Northern Song Dynasty pointillist porcelain pillows of the Jingdezhen Hutian Kiln. Sci Conserv Archaeol. 2017:29:41-46 (in Chinese)

34. Li QJ, Xu LBY, Zhang ML, Wu L, Wu J. Analysis of structure and properties of greenish white porcelain belong to Jizhou Kiln in Song Dynasty. China Ceram. 2018;54:48-53 (in Chinese)

\section{Publisher's Note}

Springer Nature remains neutral with regard to jurisdictional claims in published maps and institutional affiliations.

\section{Submit your manuscript to a SpringerOpen ${ }^{\circ}$ journal and benefit from:}

- Convenient online submission

- Rigorous peer review

- Open access: articles freely available online

- High visibility within the field

- Retaining the copyright to your article

Submit your next manuscript at $\boldsymbol{\nabla}$ springeropen.com 